\title{
STAG1 Gene
}

National Cancer Institute

\section{Source}

National Cancer Institute. STAG1 Gene. NCI Thesaurus. Code C131224.

This gene plays a role in sister chromatid binding. 